\title{
Ammonium/nitrate ratio affects the growth and glucosinolates content of pakchoi
}

\author{
Jing Yang ${ }^{1} \mathbb{D}$; Biao Zhu ${ }^{1} \mathbb{D}$; Xiaolei Ni ${ }^{2} \mathbb{D}$; Yong He ${ }^{1 \mathbb{D}}$ \\ 'Zhejiang A \& F University, Hangzhou, China; yangjing@zafu.edu.cn; billzhu@zafu.edu.cn (author for correspondence); heyong@zafu. \\ edu.cn; ${ }^{2}$ Zhejiang University, Hangzhou, China; ninina8@163.com
}

\begin{abstract}
Nitrogen (N) strongly affects plant growth. However, little is known about the effects of the ammonium/nitrate ratio on pakchoi (Brassica rapa), especially its glucosinolates (GSs) contents which are involved in plant defense and many of them benefit to human health. The aim of this study was to evaluate the effects of a constant $\mathrm{N}$ supply $(8 \mathrm{mM}$ ) but with five ammonium/nitrate ratios (namely $0 / 8$ $\mathrm{mM}, 2 / 6 \mathrm{mM}, 4 / 4 \mathrm{mM}, 6 / 2 \mathrm{mM}$ and $8 / 0 \mathrm{mM}$ ) on the growth of pakchoi in a hydroponic system in 2 years. In both years, a higher biomass (dry weight) was in the $4 / 4$ and $2 / 6$ ammonium/nitrate treatments ( 2.3 and 2.2-fold compared to 8/0, respectively), with no significant difference in biomass between these two treatments. The biomass then decreased with increasing proportions of ammonium in the $\mathrm{N}$ supply from more than $10 \mathrm{~g} /$ pot to below $5 \mathrm{~g} /$ pot. The $\mathrm{N}$ and sulfur contents were strongly affected in the sole nitrate or ammonium treatments, as were the contents of chlorophyll, lutein, and $\beta$-carotene. Most of the individual glucosinolates (GSs) detected in pakchoi showed the highest concentrations in the sole ammonium treatment. The ammonium/nitrate ratio also affected the types of GSs. The highest proportion of indolyl GSs and the lowest proportion of aromatic GSs were in the sole ammonium treatment. We concluded that a high ammonium level decreases the biomass but increases the GSs concentrations in pakchoi. Further studies are required to explore the difference in GSs metabolism among plants supplied with different ammonium/nitrate ratios.
\end{abstract}

Keywords: Brassica rapa, biomass, nitrogen form, secondary metabolites.

\section{RESUMO}

Relação amônio/nitrato afeta o crescimento e o conteúdo de glucosinolatos do pakchoi

$\mathrm{O}$ nitrogênio $(\mathrm{N})$ afeta fortemente o crescimento das plantas. No entanto, pouco se sabe sobre os efeitos da relação amônio/ nitrato no pakchoi (Brassica rapa), especialmente no conteúdo de glucosinolatos (GSs) envolvidos na defesa das plantas e muitos deles benéficos à saúde humana. $\mathrm{O}$ objetivo deste estudo foi avaliar os efeitos de um suprimento constante de $\mathrm{N}(8 \mathrm{mM})$, mas com cinco proporções de amônio/nitrato (ou seja, 0/8 mM, 2/6 mM, 4/4 mM, $6 / 2 \mathrm{mM}$ e $8 / 0 \mathrm{mM}$ ) sobre o crescimento de pakchoi em um sistema hidropônico em 2 anos. Nos dois anos, uma maior biomassa (peso seco) foi observada nos tratamentos $4 / 4$ e 2/6 de amônio/nitrato $(2,3$ e 2,2 vezes em comparação com $8 / 0$, respectivamente), sem diferença significativa na biomassa entre esses dois tratamentos. A biomassa então diminuiu com proporções crescentes de amônio no suprimento de $\mathrm{N}$ de mais de $10 \mathrm{~g} /$ vaso para menos de $5 \mathrm{~g}$ /vaso. Os teores de $\mathrm{N}$ e enxofre foram fortemente afetados nos tratamentos com nitrato ou amônio, assim como os teores de clorofila, luteína e $\beta$-caroteno. A maioria dos glucosinolatos individuais (GSs) detectados no pakchoi apresentou as maiores concentrações no tratamento com apenas amônio. A relação amônio/nitrato também afetou os tipos de GSs. A maior proporção de indolil GSs e a menor proporção de GSs aromático estavam no tratamento com apenas amônio. Concluímos que um alto nível de amônio diminui a biomassa, mas aumenta as concentrações de GSs no pakchoi. Estudos adicionais são necessários para explorar a diferença no metabolismo dos GSs entre plantas fornecidas com diferentes proporções de amônio/nitrato.

Palavras-chave: Brassica rapa, biomassa, forma de nitrogênio, metabólitos secundários.

\section{Received on August 20, 2019; accepted on April 2, 2020}

$\mathrm{G}$ lucosinolates (GSs) are nitrogen $(\mathrm{N})$ - and sulfur (S)-containing plant secondary metabolites mainly found in the order Capparales (Halkier \& Gershenzon, 2006). The GSs have a common basic structure comprising a $\beta$-D-thioglucose group, a sulfonated aldoxime moiety, and a variable side chain derived from amino acids. They are grouped into aliphatic, aromatic and indolyl GSs depending on the structure of their side-chain (Bell et al., 2018). The hydrolysis products of GSs, including thiocyanates, isothiocyanates and nitriles, have bioactive properties. In the plant, they are involved in defense against insects and phytopathogens. They have also been shown to inhibit carcinogenesis and to precaution against cardiovascular ailments and neurodegenerative diseases (Verkerk et al., 2009). Several studies have shown that GSs and their hydrolysis products participate in $\mathrm{N}$ and $\mathrm{S}$ metabolism in the plant and are regulated by environmental factors and agronomic practices (Björkman et al., 2011; 
Martínez-Ballesta et al., 2013).

Nitrogen is one of the most important nutrients in plants. It has been shown to affect the biomass and the GSs concentrations in brassicas such as broccoli (Schonhof et al., 2007). The supply of $\mathrm{N}$ as nitrate to plants, especially leafy vegetables, can affect the uptake and accumulation of nitrate, which may be harmful to human health (Chen et al., 2004). Some reports have suggested that supplying $\mathrm{N}$ in the form of ammonium instead of nitrate could reduce nitrate accumulation in plant tissues. However, a higher ratio of ammonium may lead to a significant reduction in biomass production due to ammonium toxicity (Zhang et al., 2005). Therefore, several studies have evaluated which ammonium/nitrate ratio is optimal for growing different vegetables on the balancing of good and harm (Zhang et al., 2003). The ammonium/nitrate ratio also affects the GSs profiles in brassicas. Kim et al. (2006) reported that the highest GS concentrations in rocket salad were in plants supplied with 50\% ammonium $/ 50 \%$ nitrate. Similar results were provided by La et al. (2013) in bolting stems of Chinese kale supplied with $50 \%$ ammonium $/ 50 \%$ nitrate. However, the effect of the ammonium/ nitrate ratio on GSs concentrations and profiles in pakchoi, an important dietary GS source plant in China, is still unknown. Pakchoi (Brassica rapa) is one of the main leafy vegetables grown in Asia, especially in the Yangtze River region of China with high contents of nutrient and phytochemical compounds, and also cultivated in Europe as well as America in recent decades (Qian et al., 2006; Wang et al., 2007; Yu et al., 2010). Pakchoi belongs to the genus Brassica with a wide range of morphology, and could be divided into four major diversified crops according to the appearance of their edible or useful parts, including common pakchoi which is used in this study, as well as Wutacai, Caitai and Taicai (Yu et al., 2010). The aim of this study was to investigate the effects of $\mathrm{N}$ supply at the same total $\mathrm{N}$ concentration but with different ammonium/nitrate ratios on the growth and GS profiles of pakchoi and to explore the optimal ammonium/ nitrate ratio.

\section{MATERIAL AND METHODS}

\section{Plant preparation}

Pakchoi (Brassica rapa ssp. chinensis var. communis) seedlings were grown in a glasshouse in Hangzhou (Zhejiang Province, China; $\left.30^{\circ} 15^{\prime} 36^{\prime \prime} \mathrm{N}, 120^{\circ} 11^{\prime} 24^{\prime \prime} \mathrm{E}\right)$ under a natural photoperiod from September to October. The maximum temperature during the day was about $30^{\circ} \mathrm{C}$ and the minimum temperature at night was $16^{\circ} \mathrm{C}$. The highest light intensity was about $650 \mu \mathrm{mol} \mathrm{m} \mathrm{m}^{-2} \mathrm{~s}^{-1}$ (PPFD). Seeds were germinated in vermiculite and seedlings were transplanted into a four L plastic pot (four plants per pot) three weeks after germination. The plants were treated with different ratios of ammonium $\left(\mathrm{NH}_{4}^{+}\right)$/nitrate $\left(\mathrm{NO}_{3}^{-}\right)$ with the same total $\mathrm{N}$ concentration (8 $\mathrm{mM}$ ) as follows: $\mathrm{N} 1: 0 \% \mathrm{NH}_{4}^{+}-\mathrm{N}$, $100 \% \mathrm{NO}_{3}^{-}-\mathrm{N} ; \mathrm{N} 2: 25 \% \mathrm{NH}_{4}^{+}-\mathrm{N}, 75 \%$ $\mathrm{NO}_{3}^{-}-\mathrm{N} ; \mathrm{N} 3: 50 \% \mathrm{NH}_{4}^{+}-\mathrm{N}, 50 \% \mathrm{NO}_{3}^{-}$ $-\mathrm{N} ; \mathrm{N} 4: 75 \% \mathrm{NH}_{4}^{+}-\mathrm{N}, 25 \% \mathrm{NO}_{3}^{-}-\mathrm{N}$; N5: $100 \% \mathrm{NH}_{4}^{+}-\mathrm{N}, 0 \% \mathrm{NO}_{3}^{-}-\mathrm{N}$. The nutrient solutions contained $\mathrm{K}(4.0$ $\mathrm{mM}), \mathrm{S}(1.0 \mathrm{mM}), \mathrm{Ca}(2.5 \mathrm{mM}), \mathrm{Mg}(1.0$ $\mathrm{mM}), \mathrm{P}(1.0 \mathrm{mM})$, and the following micronutrients: B $(20 \mu \mathrm{M})$, Mo $(0.1$ $\mu \mathrm{M}), \mathrm{Mn}(3 \mu \mathrm{M}), \mathrm{Zn}(2 \mu \mathrm{M}), \mathrm{Cu}(0.8$ $\mu \mathrm{M})$ and $\mathrm{Fe}(50 \mu \mathrm{M})$ as EDTA salt. The $\mathrm{pH}$ of nutrient solutions was adjusted to 6.0. The nutrient solutions $(4 \mathrm{~L} / \mathrm{pot})$ were changed twice a week. No plants died during the experiment.

Plants were harvested two weeks after the treatments. Shoots were immediately frozen in liquid $\mathrm{N}$, freezedried, weighted to determine dry mass and then ground to a fine powder and stored at $-20^{\circ} \mathrm{C}$ until analysis. The roots were dried to constant weight at $60^{\circ} \mathrm{C}$ and then weighed to determine dry mass. Each sample consisted of shoot/root from four plants, and each treatment repeated five times.

This experiment was repeated in the following year (from September to October), focusing on the GSs profiles. The maximum temperature during the day was $35^{\circ} \mathrm{C}$ and the minimum temperature at night was $18^{\circ} \mathrm{C}$. The highest light intensity was $663 \mu \mathrm{mol}$ $\mathrm{m}^{-2} \mathrm{~s}^{-1}$ (PPFD).

\section{Glucosinolates analysis}

The GSs were identified and quantified as described by Yang et al. (2009). Briefly, $0.25 \mathrm{~g}$ freeze-dried powder was extracted with $4 \mathrm{~mL}$ $70 \%$ boiling methanol and $100 \mu \mathrm{L}$ sinigrin ( $5 \mathrm{mM}$, internal standard) in a $75^{\circ} \mathrm{C}$ water bath for $10 \mathrm{~min}$. Barium acetate $(1 \mathrm{~mL}, 0.4 \mathrm{M})$ was added, the mixture was mixed quickly, and then centrifuged at $4000 \mathrm{rpm}$ for $10 \mathrm{~min}$. The supernatant was collected and the pellet was re-extracted twice with $3 \mathrm{~mL}$ $70 \%$ boiling methanol. The supernatants were combined and made up to a final volume of $10 \mathrm{~mL}$. Then, a 5-mL aliquot was loaded onto a $1 \mathrm{~mL}$ mini-column (JT Baker, USA) containing $500 \mu \mathrm{L}$ activated DEAE Sephadex ${ }^{\mathrm{TM}}$ A25 (Amersham Biosciences, Sweden), and allowed to de-sulphate overnight with aryl sulfatase (Sigma-Aldrich, USA). The resultant desulpho (ds)-GSs were eluted with $2.5 \mathrm{~mL}$ ultrapure water produced by a Milli-Q system (Millipore, USA) and stored at $-20^{\circ} \mathrm{C}$ until high performance liquid chromatography (HPLC) analysis.

A $20-\mu \mathrm{L}$ aliquot of the sample was analyzed using an Agilent 1200 HPLC system (Agilent Technologies, USA) equipped with a Prontosil ODS2 column (250 $\times 4 \mu \mathrm{m}, 5 \mu \mathrm{m}$, Bischoff, Germany) and a G1315B diode array detector (DAD) set at $229 \mathrm{~nm}$. The mobile phase was ultrapure water (A) and acetonitrile (Tedia, USA) (B) applied with a linear gradient from $0 \%$ to $20 \% \mathrm{~B}$ in $32 \mathrm{~min}$, then constant at $20 \% \mathrm{~B}$ for $6 \mathrm{~min}$, followed by $100 \% \mathrm{~B}$ and $0 \% \mathrm{~B}$ before injecting the next sample. The flow rate was $1.3 \mathrm{~mL} / \mathrm{min}$.

\section{Element measurements}

Major elements were quantified as described by Yang et al. (2009). Freezedried powdered plant tissue $(0.15 \mathrm{~g})$ was digested by mixed concentrated $\mathrm{HNO}_{3}$ and $\mathrm{HClO}_{4}$ and then analyzed to determine the $\mathrm{P}, \mathrm{S}, \mathrm{K}, \mathrm{Ca}$, and $\mathrm{Mg}$ contents by inductively coupled plasma atomic emission spectrometry (model IRIS-AP; Thermo Jarrel Ash Corp., USA). To determine the total $\mathrm{N}$ content, $0.15 \mathrm{~g}$ freeze-dried powdered plant tissue was digested with $\mathrm{H}_{2} \mathrm{SO}_{4}$, 
and then distilled in a Foss Kjeltec 2300 Analyzer Unit (FossTecator AB, Höganäs, Sweden) with 40\% (w/v) $\mathrm{NaOH}$ and $1 \%(\mathrm{w} / \mathrm{v})$ boric acid (with methyl red and bromcresol green as an indicator solution), and then titrated with $0.1 \mathrm{M} \mathrm{HCl}$ ( $\mathrm{HCl}$ was titrated with $0.1 \mathrm{M} \mathrm{NaOH}$ and adjusted to accurate $0.1 \mathrm{M})$.

\section{Pigment measurements}

The contents of $\beta$-carotene, lutein and chlorophylls ( $\mathrm{a}$ and $\mathrm{b}$ ) were determined as described previously (Yang et al., 2010). Finely ground freeze-dried plant tissue $(50 \mathrm{mg})$ was mixed with acetone $(100 \%, 5 \mathrm{~mL})$ and extracted for two $\mathrm{h}$ in the dark. After centrifugation at $1000 \mathrm{rpm}$ at $4^{\circ} \mathrm{C}$, the absorbance of the supernatant at 480, 535-551, and 663 $\mathrm{nm}$ was measured with an ultraviolet (UV)-vis spectrophotometer (Shimadzu, UV-2401PC). The concentrations of chlorophyll $\mathrm{a}$ and $\mathrm{b}$ were calculated from the absorbance values as described by Eijckelhoff \& Dekker (1997). An aliquot of the supernatant $(20 \mu \mathrm{L})$ was used to determine the $\beta$-carotene and lutein contents. The sample was separated on an LC-10AT HPLC (Shimadzu) equipped with a Spherisorb C18 column
( $5 \mathrm{~mm}, 4.0 \times 250 \mathrm{~mm}$ ). Eluted products were detected at $440 \mathrm{~nm}$ using a $10 \mathrm{~A}$ UV-Vis detector.

\section{Statistical analysis}

A completely randomized block design was used, with each pot considered as a block. Each experiment was replicated five times in the first year and four times in the second year. The data were subjected to analysis of variance (ANOVA). Mean values were compared using the least significant difference (LSD) at the 0.05 significance level.

\section{RESULTS AND DISCUSSION}

\section{Plant growth}

The shoot dry weight (DW) of pakchoi plants increased as the ammonium/nitrate ratio increased from $0 / 8(\mathrm{~N} 1)$ to $2 / 6(\mathrm{~N} 2)$ and $4 / 4(\mathrm{~N} 3)$, and then decreased to the lowest value in the 8/0 (N5) treatment (Table 1). The highest shoot DW was in the N3 treatment (50\% ammonium, 50\% nitrate) in the first year, and in the N2 treatment (25\% ammonium, $75 \%$ nitrate) in the second year $(10.70 \mathrm{~g} /$ pot and $10.37 \mathrm{~g} /$ pot; 2.3 and 2.2-fold compared to N5, respectively). However, in both years, there was no significant difference in shoot DW between the N2 and N3 treatments. The root biomass was shown no obviously different among the N1, $\mathrm{N} 2, \mathrm{~N} 3$, and N4 treatments, but showed the lowest value of $0.56 / 0.49 \mathrm{~g} /$ pot in the $100 \%$ ammonium (N5) treatment in the first/second year, respectively. This result implied that pakchoi plants grew better when $25 \%$ or $50 \%$ of $\mathrm{N}$ was supplied as ammonium. The slight differences between the two years may be due to differences in temperature and/ or light conditions.

In both years, the shoot dry matter content was significantly increased when the proportion of ammonium was $25 \%$. This trend was similar to those reported for rocket salad (Eruca sativa) and spinach (Spinacea oleracea) (Zhang et al., 2005; Kim et al., 2006). Zhang et al. (2005) suggested that spinach had the highest biomass as ammonium/ nitrate ratios were $25 / 75$ and $50 / 50$. The dry weight of rocket salad leaf also had the highest value when $\mathrm{NH}_{4}: \mathrm{NO}_{3}$ percent molar ratios (PMR-N) were 25, although it did not differ significantly

Table 1. Effects of ammonium/nitrate ratios on shoot dry weight, dry matter content and root dry weight in pakchoi plants ${ }^{\mathrm{a}}$. Hangzhou, China, Zhejiang A \& F University, 2019.

\begin{tabular}{|c|c|c|c|c|c|c|}
\hline \multirow{2}{*}{$\begin{array}{l}\mathrm{NH}_{4}^{+}-\mathrm{N}^{-} \mathrm{NO}_{3}^{-}-\mathrm{N} \\
(\mathrm{mM})\end{array}$} & \multicolumn{2}{|c|}{ Shoot dry weight $\left(\mathrm{g} \mathrm{pot}^{-1}\right)$} & \multicolumn{2}{|c|}{ Shoot dry matter content $(\%)$} & \multicolumn{2}{|c|}{ Root dry weight $\left(\mathrm{g} \mathrm{pot}^{-1}\right)$} \\
\hline & $1^{\text {st }}$ & $2^{\text {nd }}$ & $1^{\text {st }}$ & $2^{\text {nd }}$ & $1^{\text {st }}$ & $2^{\text {nd }}$ \\
\hline $0 / 8$ & $8.96 \pm 0.96 b^{b}$ & $9.12 \pm 2.20 \mathrm{ab}$ & $6.07 \pm 0.39 \mathrm{~d}$ & $5.72 \pm 0.64 b$ & $1.27 \pm 0.09 \mathrm{a}$ & $1.41 \pm 0.34 \mathrm{~b}$ \\
\hline $2 / 6$ & $10.05 \pm 1.16 \mathrm{ab}$ & $10.37 \pm 0.23 \mathrm{a}$ & $6.13 \pm 0.21 \mathrm{~d}$ & $5.96 \pm 0.70 \mathrm{~b}$ & $1.18 \pm 0.12 \mathrm{a}$ & $1.83 \pm 0.20 \mathrm{a}$ \\
\hline $4 / 4$ & $10.70 \pm 1.73 \mathrm{a}$ & $7.78 \pm 1.76 \mathrm{ab}$ & $6.85 \pm 0.30 \mathrm{c}$ & $6.36 \pm 0.78 \mathrm{~b}$ & $1.28 \pm 0.26 \mathrm{a}$ & $1.37 \pm 0.22 \mathrm{~b}$ \\
\hline $6 / 2$ & $7.80 \pm 0.26 \mathrm{c}$ & $6.69 \pm 1.76 \mathrm{bc}$ & $7.42 \pm 0.13 b$ & $6.72 \pm 0.12 \mathrm{~b}$ & $1.06 \pm 0.05 \mathrm{a}$ & $1.48 \pm 0.21 \mathrm{ab}$ \\
\hline $8 / 0$ & $4.62 \pm 0.75 \mathrm{~d}$ & $4.81 \pm 0.58 \mathrm{c}$ & $9.18 \pm 0.35 \mathrm{a}$ & $10.74 \pm 1.06 \mathrm{a}$ & $0.56 \pm 0.07 \mathrm{~b}$ & $0.49 \pm 0.08 \mathrm{c}$ \\
\hline
\end{tabular}

$1^{\text {st }}=$ first year; $2^{\text {nd }}=$ second year. ${ }^{a}$ Data are presented as mean \pm standard deviation (first year: $n=5$, second year: $n=4$ ). ${ }^{b} M e a n s$ followed by different letters in each column were significantly different $(\mathrm{p}<0.05)$.

Table 2. Effects of ammonium/nitrate ratio on the contents of N, P, S, K, Ca and $\mathrm{Mg}$ in the shoots of pakchoi in the first year. Hangzhou, China, Zhejiang A \& F University, 2019.

\begin{tabular}{lcccccc}
\hline \multirow{2}{*}{$\mathbf{N H}_{4}{ }^{+}-\mathbf{N} / \mathbf{N O}_{3}-\mathbf{N}(\mathbf{m M})$} & Nitrogen & Phosphorus & Potassium & Calcium & Magnesium & Sulphur \\
\cline { 2 - 7 } & \multicolumn{5}{c}{$\mathbf{( \mathbf { m g ~ g } ^ { - 1 } \mathbf { ~ D W } )}$} \\
\hline $0 / 8$ & $47.23 \pm 2.96 \mathrm{a}$ & $5.71 \pm 0.32 \mathrm{c}$ & $29.08 \pm 0.21 \mathrm{a}$ & $4.75 \pm 0.05 \mathrm{ab}$ & $2.73 \pm 0.11 \mathrm{a}$ & $5.67 \pm 0.09 \mathrm{~b}$ \\
$2 / 6$ & $38.93 \pm 2.65 \mathrm{c}$ & $6.43 \pm 0.42 \mathrm{~b}$ & $26.33 \pm 1.13 \mathrm{~b}$ & $4.86 \pm 0.03 \mathrm{a}$ & $2.64 \pm 0.07 \mathrm{a}$ & $5.75 \pm 0.36 \mathrm{~b}$ \\
$4 / 4$ & $41.33 \pm 2.42 \mathrm{bc}$ & $6.57 \pm 0.09 \mathrm{~b}$ & $23.69 \pm 0.74 \mathrm{c}$ & $4.83 \pm 0.13 \mathrm{ab}$ & $2.49 \pm 0.13 \mathrm{~b}$ & $5.68 \pm 0.23 \mathrm{~b}$ \\
$6 / 2$ & $42.19 \pm 1.00 \mathrm{bc}$ & $6.27 \pm 0.14 \mathrm{~b}$ & $23.83 \pm 0.37 \mathrm{c}$ & $4.72 \pm 0.04 \mathrm{~b}$ & $2.08 \pm 0.07 \mathrm{c}$ & $5.43 \pm 0.29 \mathrm{~b}$ \\
$8 / 0$ & $44.08 \pm 2.92 \mathrm{ab}$ & $7.68 \pm 0.26 \mathrm{a}$ & $24.38 \pm 0.60 \mathrm{c}$ & $4.73 \pm 0.08 \mathrm{~b}$ & $2.06 \pm 0.05 \mathrm{c}$ & $7.28 \pm 0.47 \mathrm{a}$ \\
\hline
\end{tabular}

Means followed by different letter in each column were significantly different $(\mathrm{p}<0.05)$ according to LSD test. 
among the $0,25,50$ and 75 treatments (Kim et al., 2006). The slight difference between rocket salad and pakchoi may be due to different growth stages or/ and genotypes. Ammonium toxicity symptoms (reduced shoot and root biomass, poor plant growth) were observed in the plants supplied with $100 \%$ ammonium. The physiological and biochemical mechanisms of ammonium toxicity have been discussed in several reviews (Gerendas et al., 1997; Esteban et al., 2016).

\section{Concentrations of elements}

We focused on $\mathrm{N}$ and $\mathrm{S}$ concentrations in pakchoi in this study. Because GSs are $\mathrm{N}$ - and $\mathrm{S}$ - containing compounds, $\mathrm{N}$ and $\mathrm{S}$ should play an important role in GS synthesis (Schonhof et al., 2007). The
$\mathrm{N}$ concentration in the shoots of pakchoi plants was significantly affected by the ammonium/nitrate ratio (Table 2). The highest $\mathrm{N}$ concentrations in shoots were in the $100 \%$ nitrate or $100 \%$ ammonium treatments, and the lowest was in the N2 (25\% ammonium $/ 75 \%$ nitrate) treatment. The nitrate content in pakchoi shoots decreased because of the less intake of $\mathrm{NO}_{3}^{-}-\mathrm{N}$ as the proportion of ammonium in the $\mathrm{N}$ supply increased.

The $\mathrm{S}$ concentration in shoots was not markedly affected by the ammonium/ nitrate ratio, except that there was a significant increase $(22 \%)$ in the $100 \%$ from $50 \%$ ammonium treatment. This might be partly due to a concentration effect. The concentrations of $\mathrm{P}, \mathrm{K}, \mathrm{Ca}$, and $\mathrm{Mg}$ in pakchoi shoots were also measured (Table 2) in the first year. The $\mathrm{K}^{+}, \mathrm{Ca}^{2+}$ and $\mathrm{Mg}^{2+}$ concentrations were lower in the treatments with more than $50 \%$ of the $\mathrm{N}$ supply as ammonium. This might reflect the need for cationanion balance and the maintenance of intracellular $\mathrm{pH}$ in pakchoi supplied with high levels of ammonium (Kim et al., 2006; Marschner, 2011).

\section{Changes in pigment contents}

To evaluate the effect of the $\mathrm{N}$ form on photosynthesis, we measured the chlorophyll ( $\mathrm{a}$ and $\mathrm{b}$ ), lutein and $\beta$-carotene contents of pakchoi shoots in the first year. The concentrations were calculated on a DW and fresh weight (FW) basis. The chlorophyll a/b ratio and all of the measured pigments except for chlorophyll $b$ showed the

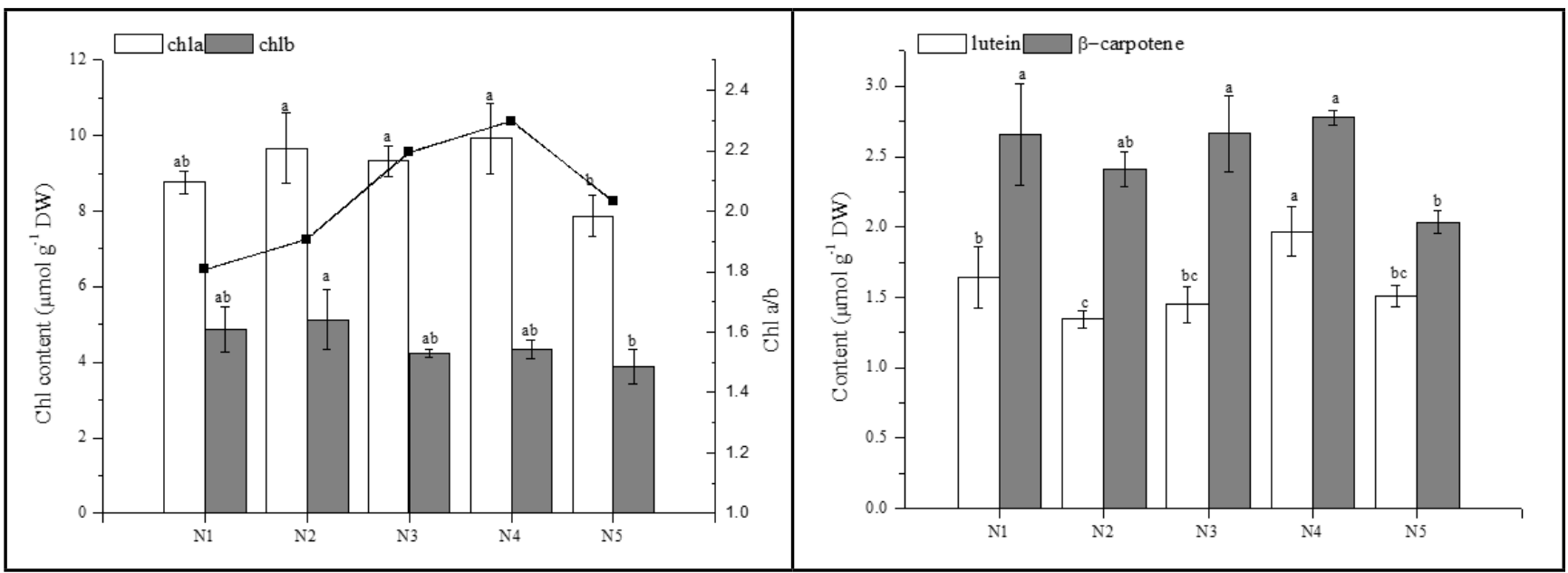

Figure 1. Effects of ammonium/nitrate ratio on the concentrations of chlorophyll, lutein and $\beta$-carotene base on dry weight (DW) in pakchoi shoots in the first year. Hangzhou, China, Zhejiang A \& F University, 2019.

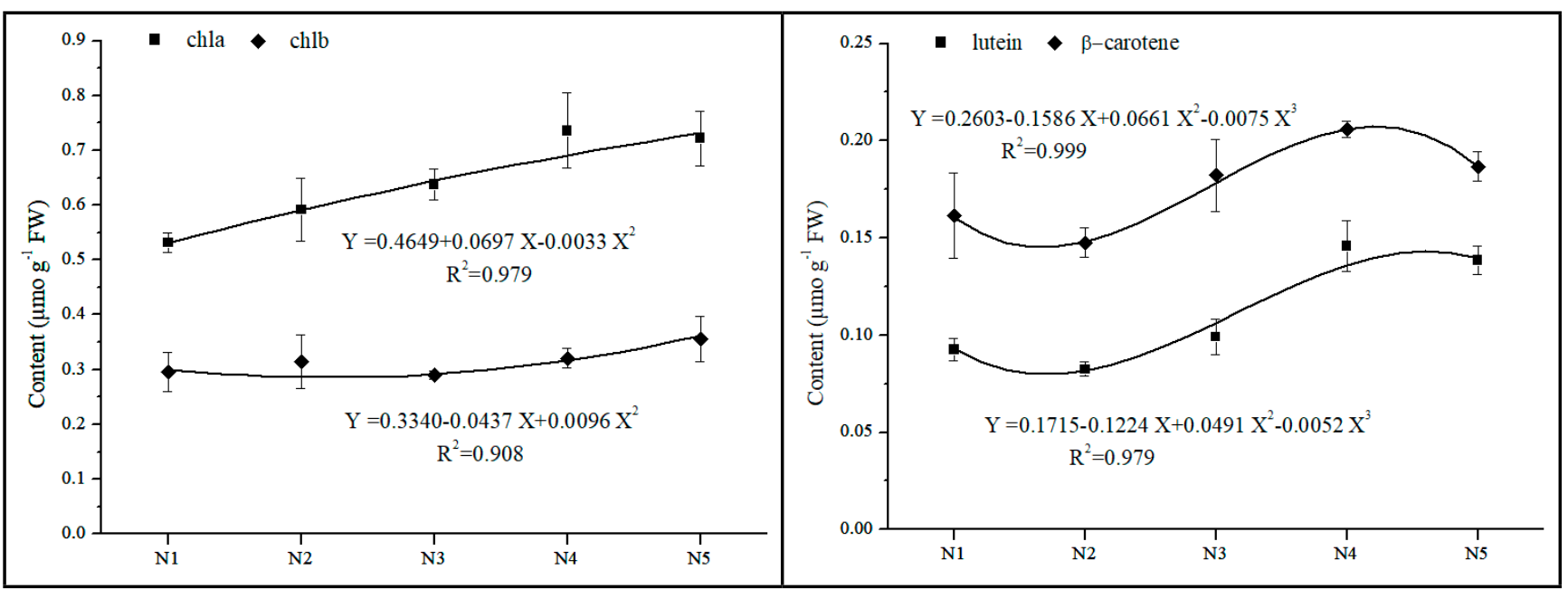

Figure 2. Effects of ammonium/nitrate ratio on the concentrations of chlorophyll, lutein and $\beta$-carotene base on fresh weight (FW) in pakchoi shoots in the first year. Hangzhou, China, Zhejiang A \& F University, 2019. 
highest values in the N4 treatment (Figures 1 and 2). The concentrations of chlorophyll a and b (based on DW) did not differ significantly among the five treatments. However, the concentrations of chlorophyll a (based on FW), lutein and $\beta$-carotene showed significant or highly significant differences among the five treatments. The concentration of chlorophyll a (based on FW) showed a significant quadratic response to the $\mathrm{N}$ form (Figure 1), while the concentrations of lutein and $\beta$-carotene showed more complex responses (Figure 2). The results of several previous studies have indicated that the $\mathrm{N}$ form affects the concentrations of pigments including chlorophylls, lutein, and xanthophyll (Bonasia et al., 2015; Barickman \& Kopsell, 2016). Bonasia et al. (2015) showed that the chlorophyll content was raised by ammonium in endive which consists with our results in pakchoi, and it is possible to observe a decrease as a result of ammonium toxicity in ammonium intolerant species. They also hypothesize that no negative repercussions on photosynthesis occurred in $\mathrm{NH}_{4}^{+}-\mathrm{N}$-fed endive. Barickman \& Kopsell (2016) suggested that a fertility program of $25 \%$ $\mathrm{NH}_{4}-\mathrm{N}: 75 \% \mathrm{NO}_{3}-\mathrm{N}$ is recommended for increased biomass accumulation and health promoting carotenoid and chlorophyll concentrations in the leaf tissue of Swiss Chard.

\section{Individual glucosinolates}

Seven individual GSs were detected in pakchoi shoots (Table 3). These GSs belonged to three groups: aliphatic GSs (glucoalyssin, gluconapin and glucobrassicanapin), indolyl GSs (glucobrassicin, 4-methoxyglucobrassicin and neoglucobrassicin) and aromatic GSs (gluconasturtiin). The major compounds were the aliphatic GSs gluconapin and glucobrassicanapin, which accounted for more than $50 \%$ and $20 \%$ of the total GSs in the first and second year, respectively. The concentrations of all seven GSs increased when more than $25 \%$ and $50 \%$ of $\mathrm{N}$ was supplied as ammonium in the first and second year, respectively. Most GSs showed peak values in the sole ammonium treatment in the first year, and in the sole ammonium and/ or nitrate in the second year, except for 4-methoxyglucobrassicin, which showed the highest value in the N4 $(75 \%$ ammonium $/ 25 \%$ nitrate treatment in both years). The results of the ANOVA indicated that all seven GSs were significantly influenced by the $\mathrm{N}$ form. Therefore, the ammonium/nitrate ratio in the $\mathrm{N}$ supply is likely to be a factor

Table 3. Effects of ammonium/nitrate ratios on the concentrations of individual glucosinolates in pakchoi shoots ${ }^{\mathrm{a}}$. Hangzhou, China, Zhejiang A \& F University, 2019.

\begin{tabular}{|c|c|c|c|c|c|}
\hline \multirow{2}{*}{\multicolumn{2}{|c|}{$\begin{array}{l}\mathrm{NH}_{4}^{+}-\mathrm{N} / \mathrm{NO}_{3}-\mathrm{N} \\
(\mathrm{mM})\end{array}$}} & Glucoalyssin & Gluconapin & Glucobrassicanapin & Glucobrassicin \\
\hline & & \multicolumn{4}{|c|}{$(\mu \mathrm{mol} \mathrm{g}-1 \mathrm{DW})$} \\
\hline \multirow{5}{*}{$1^{\text {st }}$} & $0 / 8$ & $0.16 \pm 0.03 \mathrm{~d}^{\mathrm{b}}$ & $3.12 \pm 0.47 \mathrm{c}$ & $1.48 \pm 0.08 \mathrm{c}$ & $0.23 \pm 0.03 \mathrm{bc}$ \\
\hline & $2 / 6$ & $0.17 \pm 0.06 \mathrm{~d}$ & $3.50 \pm 0.71 \mathrm{c}$ & $1.43 \pm 0.29 \mathrm{c}$ & $0.18 \pm 0.03 \mathrm{c}$ \\
\hline & $4 / 4$ & $0.24 \pm 0.04 \mathrm{c}$ & $3.61 \pm 0.50 \mathrm{c}$ & $1.77 \pm 0.16 \mathrm{bc}$ & $0.18 \pm 0.03 \mathrm{c}$ \\
\hline & $6 / 2$ & $0.30 \pm 0.06 \mathrm{~b}$ & $4.76 \pm 1.30 \mathrm{~b}$ & $2.17 \pm 0.53 b$ & $0.27 \pm 0.04 \mathrm{~b}$ \\
\hline & $8 / 0$ & $0.68 \pm 0.10 \mathrm{a}$ & $7.25 \pm 1.20 \mathrm{a}$ & $3.87 \pm 0.82 \mathrm{a}$ & $0.71 \pm 0.15 \mathrm{a}$ \\
\hline \multirow{5}{*}{$2^{\text {nd }}$} & $0 / 8$ & $0.12 \pm 0.04 \mathrm{~b}$ & $4.92 \pm 0.15 \mathrm{a}$ & $1.47 \pm 0.60 \mathrm{bc}$ & $0.19 \pm 0.06 \mathrm{c}$ \\
\hline & $2 / 6$ & $0.17 \pm 0.06 \mathrm{~b}$ & $2.74 \pm 0.68 \mathrm{bc}$ & $1.22 \pm 0.17 \mathrm{c}$ & $0.10 \pm 0.04 \mathrm{c}$ \\
\hline & $4 / 4$ & $0.17 \pm 0.03 \mathrm{~b}$ & $2.54 \pm 0.32 \mathrm{c}$ & $1.02 \pm 0.05 \mathrm{c}$ & $0.07 \pm 0.02 \mathrm{c}$ \\
\hline & $6 / 2$ & $0.18 \pm 0.01 \mathrm{~b}$ & $4.12 \pm 1.08 \mathrm{ab}$ & $1.89 \pm 0.27 \mathrm{ab}$ & $0.51 \pm 0.09 \mathrm{~b}$ \\
\hline & $8 / 0$ & $0.35 \pm 0.10 \mathrm{a}$ & $4.35 \pm 1.18 \mathrm{a}$ & $2.15 \pm 0.30 \mathrm{a}$ & $0.72 \pm 0.16 \mathrm{a}$ \\
\hline \multirow{2}{*}{\multicolumn{2}{|c|}{$\begin{array}{l}\mathrm{NH}_{4}^{+}-\mathrm{N} / \mathrm{NO}_{3}^{-}-\mathrm{N} \\
(\mathrm{mM})\end{array}$}} & Gluconasturtiin & 4-methoxyglucobrassicin & Neoglucobrassicin & \\
\hline & & \multicolumn{3}{|c|}{$\left(\mu \mathrm{mol} \mathrm{g}{ }^{-1} \mathrm{DW}\right)$} & \\
\hline \multirow{5}{*}{$1^{\text {st }}$} & $0 / 8$ & $0.72 \pm 0.14 \mathrm{a}$ & $0.032 \pm 0.008 \mathrm{~b}$ & $0.29 \pm 0.12 \mathrm{bc}$ & \\
\hline & $2 / 6$ & $0.47 \pm 0.11 \mathrm{~b}$ & $0.021 \pm 0.004 \mathrm{c}$ & $0.23 \pm 0.06 \mathrm{c}$ & \\
\hline & $4 / 4$ & $0.70 \pm 0.11 \mathrm{a}$ & $0.026 \pm 0.010 \mathrm{bc}$ & $0.34 \pm 0.09 \mathrm{bc}$ & \\
\hline & $6 / 2$ & $0.65 \pm 0.15 \mathrm{a}$ & $0.045 \pm 0.017 \mathrm{a}$ & $0.40 \pm 0.08 \mathrm{~b}$ & \\
\hline & $8 / 0$ & $0.82 \pm 0.22 \mathrm{a}$ & $0.035 \pm 0.014 \mathrm{~b}$ & $1.19 \pm 0.21 \mathrm{a}$ & \\
\hline \multirow{5}{*}{$2^{\text {nd }}$} & $0 / 8$ & $0.37 \pm 0.10 \mathrm{a}$ & $0.018 \pm 0.004 \mathrm{a}$ & $0.18 \pm 0.01 \mathrm{c}$ & \\
\hline & $2 / 6$ & $0.31 \pm 0.02 \mathrm{ab}$ & $0.012 \pm 0.000 \mathrm{~b}$ & $0.13 \pm 0.03 \mathrm{~cd}$ & \\
\hline & $4 / 4$ & $0.22 \pm 0.03 \mathrm{~b}$ & $0.011 \pm 0.001 \mathrm{~b}$ & $0.12 \pm 0.04 \mathrm{~d}$ & \\
\hline & $6 / 2$ & $0.30 \pm 0.02 \mathrm{ab}$ & $0.022 \pm 0.001 \mathrm{a}$ & $0.26 \pm 0.01 \mathrm{~b}$ & \\
\hline & $8 / 0$ & $0.36 \pm 0.06 \mathrm{a}$ & $0.020 \pm 0.005 \mathrm{a}$ & $0.45 \pm 0.03 \mathrm{a}$ & \\
\hline
\end{tabular}

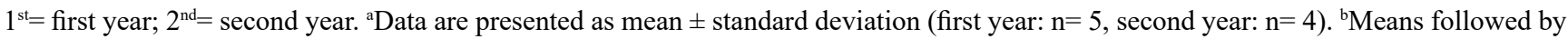
different letter in each column in each year were significantly different $(p<0.05)$. 


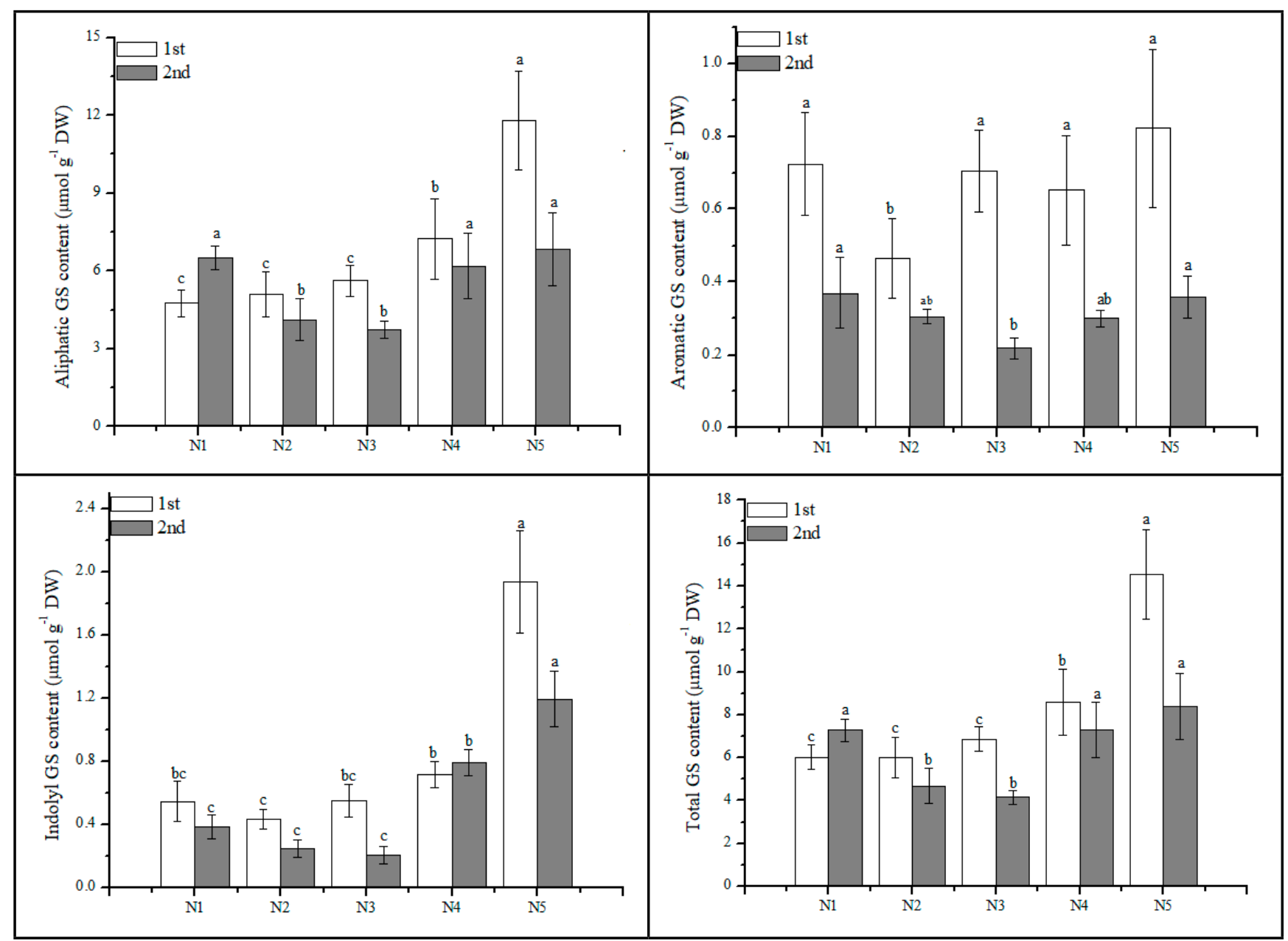

Figure 3. Effects of ammonium/nitrate ratio on the concentrations of aliphatic, indolyl, aromatic and total glucosinolates in pakchoi shoots. Hangzhou, China, Zhejiang A \& F University, 2019.

that affects GS synthesis in pakchoi.

The ammonium/nitrate ratio could affect the quality and nutritional value of vegetables according to changes in their GS contents. Upon tissue disruption, intact GSs are hydrolyzed by thioglucosidase [myrosinases (EC 3.2.3.1)]. The hydrolyzed forms are thought to be the bioactive forms of GSs. For example, gluconasturtiin (2-phenethyl glucosinolate) and glucobrassicin are hydrolyzed to form phenethyl-isothiocyanate and indole3-carbinol, respectively, which were shown to reduce carcinogen activation (Higdon et al., 2007). Furthermore, some GSs affect the flavor of the plant. For example, isothiocyanates derived from gluconapin and glucobrassicanapin might reduce palatability (Abe et al., 2015; Bell et al., 2018). The results of the present study implied that GS metabolism was up-regulated as the proportion of ammonium in the $\mathrm{N}$ supply increased from $25 \%$ to $75 \%$, consistent with the results of Kim et al. (2006). The ammonium/nitrate ratio may also affect the composition of hydrolyzed GSs, which may affect the palatability and nutritional value of pakchoi.

Total glucosinolates and glucosinolate profiles

The total GSs concentration was significantly increased when the $\mathrm{N}$ supply contained more than $50 \%$ ammonium, and peaked in the $100 \%$ ammonium treatment (Figure 3). In the first year, the total GSs concentration in the $100 \%$ ammonium treatment was $141.5 \%$ of that in the $100 \%$ nitrate treatment, while the difference was smaller in the second year. The results of Marino et al. (2016) both in broccoli and Arabidopsis also showed significant increase of total GSs contents with ammonium as the nitrogen source compared to nitrate.

Analyses of individual GSs revealed that aliphatic GSs were the major component of total GSs in pakchoi 'You Dong Er', accounting for 79\% to $90 \%$ of the total GSs content. In the first year, the aliphatic GSs content was much higher in the $100 \%$ ammonium treatment than in the other treatments, but this difference was much smaller in the second year. In contrast, total indolyl GSs showed similar changes in the two years with respect to the ammonium/nitrate ratio. The highest concentration of indolyl GSs was in the $100 \%$ ammonium treatment. The differences in indolyl GSs contents among the N1, N2 and N3 treatments were not significant. The aromatic GSs concentration was less affected by the ammonium/nitrate ratio, but was significantly lower in the $25 \%$ and $50 \%$ 
ammonium treatments than in the other treatments in the first and second years, respectively.

In rocket supplied with different ammonium/nitrate ratios, the total GSs content increased with increasing proportions of ammonium, but showed a marked decrease in the $100 \%$ ammonium treatment (Kim et al., 2006). The discrepancy between the findings of that study and our findings may be due to differences in tolerance to ammonium toxicity between different vegetable species, or to differences in plant growth stages or other experimental conditions. The sharp decrease in shoot DW in our experiment may also have contributed to the increased GSs concentration with increasing ammonium/nitrate rate; that is, it may represent a concentration effect. As reported by La et al. (2013), in Chinese kale bolting stem, the total GSs concentration gradually increased as the proportion of ammonium increased $0 \%$ to $50 \%$, and the peak value was achieved at $50 \%$ ammonium, different from our results. The reasons for the differences between their results and ours may be due to variations in GSs contents among different plant parts, and/or genetic differences in GSs contents between species. In our previous study, we detected large differences in GSs contents among various organs of pakchoi (Zhu et al., 2013).

Combining the data of elements concentration, the $\mathrm{N}$ form (probably ammonium) play a role in GS synthesis, since the $\mathrm{N}$ concentrations did not change significantly when the proportion of ammonium was higher than $50 \%$. The increased $\mathrm{S}$ concentration (based on DW) in the $100 \%$ ammonium treatment may have contributed to the accumulation of GSs, especially indolyl GSs. The ratios of $\mathrm{N}$ and other elements, especially $\mathrm{S}$, probably indirectly affect GSs metabolism. Further studies should be conducted to explore the mechanisms of GSs accumulation and the effects of different nutrient forms (especially $\mathrm{N}$ and S) on the growth and GSs profiles of pakchoi.

\section{ACKNOWLEDGEMENTS}

This research was financially supported by National Natural Science Foundation of China (NSFC, 31972394 , 31501748).

\section{REFERENCES}

ABE, K; KIDO, S; MAEDA, T; KAMI, D; MATSUURA, H; SHIMURA, H; SUZUKI, T. 2015. Glucosinolate profiles in Cardamine fauriei and effect of light quality on glucosinolate concentration. Scientia Horticulturae 189: 12-16.

BARICKMAN, TC; KOPSELL, DA. 2016, Nitrogen form and ratio impact Swiss Chard (Beta vulgaris subsp. cicla) Shoot tissue carotenoid and chlorophyll concentrations. Scientia Horticulturae 204: 99-105.

BELL, L; OLOYEDE, OO; LIGNOU, $\mathrm{S}$; WAGSTAFFF, C; METHVEN, L. 2018. Taste and flavour perceptions of glucosinolates, isothiocyanates, and related compounds. Molecular Nutrition \& Food Research, 1700990.

BJÖRKMAN, M; KLINGEN, I; BIRCH, ANE; BONES, AM; BRUCE, TJA; JOHANSEN, TJ; MEADOW, R; MØLMANN, J; SELJÅSEN, R; SMART, LE; STEWART, D. 2011. Phytochemicals of brassicaceae in plant protection and human health-influences of climate, environment and agronomic practice. Phytochemistry 72: 538-556.

BONASIA, A; CONVERSA, G; GONNELLA, M; SERIO, F; SANTAMARIA, P. 2015. Effects of ammonium and nitrate nutrition on yield and quality in endive. Journal of Horticultural Science and Biotechnology 83: 64-70.

CHEN, BM; WANG, ZH; LI, SX; WANG, GX; SONG, HX; WANG, XN. 2004. Effects of nitrate supply on plant growth, nitrate accumulation, metabolic nitrate concentration and nitrate reductase activity in three leafy vegetables. Plant Science 167: 635-643.

ESTEBAN, R; ARIZ, I; CRUZ, C; MORAN, JF. 2016. Review: mechanisms of ammonium toxicity and the quest for tolerance. Plant Science 248: 92-101.

EIJCKELHOFF, C; DEKKER, TP. 1997. A routine method to determine the chlorophyll a, pheophytin a and $\beta$-carotene contents of isolated photosystem II reaction center complexes. Photosynthesis Research 52: 69-73.

GERENDAS, J; ZHU, ZJ; BENDIXEN, R; RATCLIFFE, RG; SATTELMACHER, B. 1997. Physiological and biochemical processes related to ammonium toxicity in higher plants. Zeitschrift für Pflanzenernährung und Bodenkunde 160: 239-251.

HALKIER, BA; GERSHENZON, J. 2006. Biology and biochemistry of glucosinolates. Annual Review of Plant Biology 57: 303-333.

HIGDON, JV; DELAGE, B; WILLIAMS, DE; DASHWOOD, RH. 2007. Cruciferous vegetables and human cancer risk, epidemiologic evidence and mechanistic basis. Pharmacological Research 55: 224-236.
KIM, SJ; KAWAHARADA, C; ISHI, G. 2006. Effect of ammonium: nitrate nutrient ratio on nitrate and glucosinolate contents of hydroponically-grown rocket salad (Eruca sativa Mill.). Soil Science and Plant Nutrition 52: 387-393.

LA, GX; YANG, TG; FANG, P; GUO, HX; HAO, X; HUANG, SM. 2013. Effect of $\mathrm{NH}_{4}^{+} / \mathrm{NO}_{3}^{-}$ratios on the growth and bolting stem glucosinolate content of Chinese kale (Brassica alboglabra L.H. Bailey). Australian Journal of Crop Science 7: 618-624.

MARINO, D; ARIZ, I; LASA, B; SANTAMARÍA, E; FERNÁNDEZIRIGOYEN, J; GONZÁLEZ-MURUA, C; APARICIO TEJO, PM. 2016. Quantitative proteomics reveals the importance of nitrogen source to control glucosinolate metabolism in Arabidopsis thaliana and Brassica oleracea. Journal of Experimental Botany 67: 33133323.

MARSCHNER, P. 2011. Marschner's mineral nutrition of higher plants, $3^{\text {rd }}$ ed. London: Academic Press. p135-151.

MARTÍNEZ-BALLESTA, MDC; MORENO, DA; CARVAJAL, M. 2013. The Physiological Importance of glucosinolates on plant rResponse to abiotic stress in Brassica. International Journal of Molecular Sciences 14: 11607-11625.

QIAN, W; MENG, J; LI, M; FRAUEN, M; SASS, O; NOACK, J; JUNG, C. 2006. Introgression of genomic components from Chinese Brassica rapa contributes to widening the genetic diversity in rapeseed (B. napus L.), with emphasis on the evolution of Chinese rapeseed. Theoretical \& Applied Genetics 113: 49-54.

SCHONHOF, L; BLANKENBURG, D; MÜLLER, A; KRUMBEIN, A. 2007. Sulfur and nitrogen supply influence growth, product appearance, and glucosinolate concentration of broccoli. Journal of Plant Nutrition and Soil Science 170: 65-72.

VERKERK，R； SCHREINER，M； KRUMBEIN, A; CISKA, E; HOLST, B; ROWLAND, I; SCHRIJVER, RD; HANSEN, M; GERHÄUSER, C; MITHEN, R; DEKKER, M. 2009. Glucosinolates in Brassica vegetables: the influence of the food supply chain on intake, bioavailability and human health. Molecular Nutrition \& Food Research 53: S219-S265.

WANG, HJ; WU, LH; WANG, MY; ZHU, YH; TAO, QN; ZHANG, F. 2007. Effects of amino acids replacing nitrate on growth, nitrate accumulation, and macroelement concentrations in pak-choi (Brassica chinensis L.). Pedosphere 17: 595-600.

YANG, J; ZHU, ZJ; GERENDAS, J. 2009. Interactive effects of phosphorus supply and light intensity on glucosinolates in pakchoi (Brassica campestris L. ssp. chinensis var. communis). Plant Soil 323: 323-333.

YANG, J; ZHU, ZJ; WANG, ZZ, ZHU, B. 2010. Effects of storage temperature on the contents of carotenoids and glucosinolates in pakchoi (Brassica rapa L. ssp. chinensis var. communis). Journal of Food Biochemistry 34: 1186-1204. 
YU, SC; ZHANG, FL; WANG, XY; ZHAO, XY; ZHANG, DS; YU, YJ; XU, JB. 2010. Genetic diversity and marker-trait associations in a collection of pak-choi (Brassica rapa $\mathrm{L}$. ssp. chinensis Makino) accessions. Genes \& Genomics 32: 419-428.

ZHANG, FC; KANG, SZ; ZHANG, JH.
2003. Growth and ion uptake by cabbage supplied different $\mathrm{NH}_{4}^{+} / \mathrm{NO}_{3}^{-}$ratios. Journal of Experimental Botany 54: 31-31.

ZHANG, YP; LIN, XY; ZHANG, YS; DU, ST. 2005. Effects of nitrogen forms on content and distribution of nitrate and oxalate forms in spinach plants. Acta Horticulturae Sinica
32: 648-652.

ZHU, B; YANG, J; ZHU, ZJ. 2013. Variation in glucosinolates in pak choi cultivars and various organs at different stages of vegetative growth during the harvest period. Journal of Zhejiang University Science B 14: 309-317. 